\title{
Bead-based assay for spatiotemporal gene expression control in cell-free transcription-translation systems
}

$\overline{\text { Marc Finkler }{ }^{1} \text { \& Albrecht Ott*,1 }}$

\section{ABSTRACT}

Cell-free gene expression has applications in synthetic biology, biotechnology and biomedicine. In this technique gene expression regulation plays an important role. Transcription factors do not completely suppress expression while other methods for expression control, for example, CRISPR/Cas, often require important biochemical modifications. Here we use an all Escherichia coli-based cell-free expression system and present a beadbased method to instantly start and, at a later stage, completely stop gene expression. Magnetic beads coated with DNA of the gene of interest trigger gene expression. The expression stops if we remove the bead-bound DNA as well as transcribed mRNA by hybridization to bead-bound ssDNA. Our method is a simple way to control expression duration very accurately in time and space.

\section{METHOD SUMMARY}

In our paper we present a new method that enables control of gene expression in an Escherichia coli-based cell-free expression system. Using paramagnetic, DNA-coated beads we introduce and remove not only the DNA of interest, but also endogenous mRNA to achieve, almost instantly, full activation or suppression of gene expression without affecting or modifying the expression system biochemically.

\section{KEYWORDS:}

cell-free expression - Escherichia coli cell extract $\cdot$ microbeads - transcription control $\cdot$ translation control

'Universität des Saarlandes, Biologische Experimentalphysik, NaturwissenschaftlichTechnische Fakultät, B2 1, Campus, 66123 Saarbrücken, Germany; *Author for correspondence: albrecht.ott@physik. uni-saarland.de

BioTechniques 66: 29-33 (January 2019)

10.2144/btn-2018-0097

\section{INTRODUCTION}

The use of cell-free expression systems can avoid some of the difficulties linked to host organisms. For instance, toxic substances will kill the host [1] while, in most cases, a cell-free system will continue to perform [2]. The control of different biochemical parameters and processes is often simpler in vitro [3]. Many different applications of cell-free expression systems in synthetic biology, biotechnology and biomedicine require the expression of genes and their regulation or control [4-6].

A common method for transcription control is the use of inducible promoters. The presence of an inducer instantly starts transcription [7,8]. Examples of inducers include different metabolites, antibiotics and steroids [7]. Stopping transcription requires complete removal of the inducer, which is difficult without affecting the expression system. A different method to control transcription uses repressing transcription factors recognizing specific DNA sequences or specific DNA modifications such as methylation [9]. However, due to basal transcription, complete suppression cannot be achieved $[9,10]$. A light-dependent gene switch enables transcription as a response to visible light $[7,11,12]$, but the problem with basal transcription remains [12]. CRISPR/Cas switches genes on and off much more efficiently than transcription factors. The usage of arbitrary crRNA mediates the direction of Cas 9 to the DNA sequence of interest $[8,13,14]$. However, CRISPR/Cas requires biochemical modification of the expression system.

There are substances that stop transcription at the level of the RNA polymerase (Tagetin $^{\text {TM }}$, Rifampicin) or by mRNA cleavage (MazF) [15-18]. Suppression is efficient, but once included in the expression system, future expression is prevented.
Here we present a bead-based method that addresses transcription and translation control in an E. coli cell-free system. The method has no influence on the gene expression ability of the expression system. The method can be used to express genes locally, within a defined time window.

\section{MATERIALS \& METHODS}

All experiments were performed using an E. coli cell-free system described previously $[19,20]$. For the preparation of DNA-coated beads, the plasmid pBestp15a-Or2-Or1-Pr-UTR1-deGFP-6xHis-T500 was derived from the commercially available plasmid pBest-Or2-Or1-Pr-UTR1deGFP-T500 (Addgene Cat\# 40019) by replacing the ColE1 ori with the p15a ori (to reduce background expression during plasmid amplification [20]) and adding a C-terminal His-tag DNA sequence to the degfp gene. The derived plasmid was used as a template for a $\mathrm{PCR}$ reaction using Q5-Polymerase (Q5 ${ }^{\circledR}$ High-Fidelity DNA Polymerase, Neb) and the primers BiotinTEG-Seq1 (TEG stands for TriEthylene Glycol) (5'-Biotin-TEG-CAC CAT CAG CCA GAA AAC C-3', Metabion) and Seq4 (5'-GAG CTG ACT GGG TTG AAG G-3', Metabion) to amplify biotinylated Seq1-Or2-Or1-Pr-

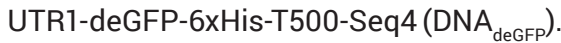
The PCR product was purified using a PureLink" PCR Purification Kit (Invitrogen). Subsequently the product was bound to streptavidin-coated magnetic beads T1 (Dynabeads ${ }^{\circledR}$ MyOne ${ }^{m}$ Streptavidin T1, Invitrogen) following the bead manufacturer's protocol [21]. The T1-Biotin-TEGSeq1-Or2-Or1-Pr-UTR1-deGFP-6xHis-

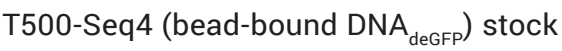
solution was at $400 \mathrm{nM}$ (DNA deGFP -concentration) in water. Two neodymium cube magnets (WM-20x20x20-N, Magnet-shop, Germany) served for bead separation.

Streptavidin-coated magnetic beads T1 were coated with single-stranded biotinylated DNA complementary to 
the 3 '-end of the Seq1-Or2-Or1-PrUTR1-deGFP-6xHis-T500-Seq4-mRNA (3') (5'-Biotin-TEG-CGG CGG GCT TTG CTC GAG TTA GTG GTG ATG GTG ATG-3', Metabion). Poly-T-coated beads (poly-T) (Dynabeads' Oligo(dT) ${ }_{25}$, Invitrogen), complementary to the poly $(A)$ tail of the transcribed mRNA, were used without further purification. The aqueous stock solution of the 3 '-coated beads was prepared at the same bead concentration as the poly-T-coated beads $(5 \mathrm{mg} / \mathrm{ml})$.

DNA concentration was determined using a spectrophotometer (NanoDrop" 2000c Spectrophotometer, Thermo Scientific). DeGFP was quantified by transferring $10 \mu \mathrm{l}$ of sample to a microwell plate (Nunc"' 384-Well Optical Bottom Plates \# 242764, Thermo Scientific) and determining the fluorescence intensity with a microplate reader (POLARstar OPTIMA, BMG LABTECH).

To $30 \mu$ l of crude $E$. coli cell-free extract we added: $3.6 \mu \mathrm{l}$ magnesium glutamate (at $100 \mathrm{mM}$ ), 2,4 $\mu$ l potassium glutamate (at $3 \mathrm{M}), 6.43 \mu$ I PGA-buffer (3-PhosphoGlyceric Acid) (14x), $4.5 \mu \mathrm{l} 40 \%$ (v/v) PEG8000, $13.07 \mu \mathrm{l}$ amino acids (mixture contains all canonical amino acids at $6 \mathrm{mM}$ except Leu at $5 \mathrm{mM}$ ) and $3 \mu \mathrm{l}$ Gams (Shortened lambda phage Gam protein) (at $99 \mu \mathrm{M})$ to reach a total of $63 \mu \mathrm{l}$, aliquoted in $8.4 \mu \mathrm{l}$ (seven samples in batch). According to Shin et al. [20] the amount for magnesium glutamate, potassium glutamate and amino acids has to be adjusted for each stock of crude extract to optimize the cell-free protein synthesis. GamS was added to prevent degradation of linear DNA [15,22-24]. For expression we used a reaction volume of $12 \mu \mathrm{l}$ by adding $3.6 \mu \mathrm{l}$ of different DNA $\mathrm{deGFP}^{-}$ solutions and double-distilled water to the $8.4 \mu \mathrm{l}$ aliquots. Concentrations of

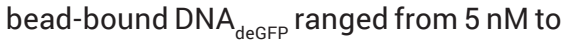
$120 \mathrm{nM}$. As a reference, unbound DNA $A_{\text {deGFP }}$ was added at $10 \mathrm{nM}$ (this concentration leads to optimal protein yield).

All chemicals involved in sample preparation and the sample itself were put on ice until expression was started by raising the temperature. To study the optimal bead-bound DNA deGFP $_{\text {concen- }}$ tration for protein yield, samples were incubated at $29^{\circ} \mathrm{C}$ for $16 \mathrm{~h}$. Then beads were separated and the fluorescence intensity was measured. Similar fluorescence intensities were measured when using $10 \mathrm{nM}$ unbound DNA $\mathrm{deGFP}_{\text {(optimal }}$ for protein yield) $(54132,6 \pm 1680,87$ a.u. $)$ and $50 \mathrm{nM}$ bead-bound DNA $\mathrm{DegFP}$ (52551,4 4 4329,48 a.u.). Therefore, $50 \mathrm{nM}$ of bead-bound DNA deGFP $_{\text {was }}$ wased in all further expression reactions (addition of 1-5 $\mu$ l of T1-Biotin-TEG-Seq1-Or2-Or1Pr-UTR1-deGFP-6xHis-T500-Seq4 stock solution and $2.1 \mu \mathrm{l}$ double-distilled water to $8.4 \mu$ l aliquots).

To study transcription, expression reactions were incubated at $29^{\circ} \mathrm{C}$ for different time periods ( $\mathrm{T}$ from $1 \mathrm{~min}$ to $16 \mathrm{~h}$ ) followed by bead separation. The samples were again incubated at $29^{\circ} \mathrm{C}$ for $\mathrm{T}_{\text {res }}=16 \mathrm{~h}-\mathrm{T}$ to reach a summed incubation time of $16 \mathrm{~h}$ at $29^{\circ} \mathrm{C}$. Subsequently the fluorescence intensity was measured (Figure 1).

To study translation, the expression reaction was incubated for $30 \mathrm{~min}$ at $29^{\circ} \mathrm{C}$. Then the bead-bound DNA degFP $_{\text {. }}$ was separated, and the supernatant was transferred to a vial containing freshly prepared ss-DNA-coated beads. The ss-DNA-coated beads consisted of $50 \mu \mathrm{l} 3^{\prime}$ and $50 \mu \mathrm{l}$ poly-Tcoated (complementary sequences to the deGFP-mRNA) beads at $5 \mathrm{mg} /$ $\mathrm{ml}$, prepared according to specifications from the manufacturer [25]. The mixture was incubated on a shaker for $15 \mathrm{~min}$ at room temperature at $230 \mathrm{rpm}$. Subsequently the ssDNA-coated beads were removed and the time course of fluorescence intensity was recorded by a microplate reader to visualize expression kinetics (Figure 2). To restart expression, $10 \mathrm{nM}$ unbound DNA $\mathrm{deGFP}$ was added to the sample immediately after ssDNA-coated bead separation, and the expression kinetics was visualized. As a reference a measurement of the kinetics without mRNA removal was performed (Figure 2).

\section{RESULTS \& DISCUSSION}

Both experiments are illustrated in Figure 3.

In a first set of experiments, we focused on controlling transcription duration. The experiments were performed as illustrated in Figure 3A. Figure 1 shows the measured fluorescence intensity after
$16 \mathrm{~h}$ of incubation for different periods $T$ of initial exposure to bead-bound DNA $_{\text {deGFP. }}$ During the incubation period the time course of fluorescence intensity corresponds to the black squares in Figure 2. Data in Figure 1 give the end points of this type of measurement.

Figure 1 shows that 30 min of DNA $A_{\text {deGFP }}$ in contact with a cell-free expression system leads to optimal protein yield. For only $1 \mathrm{~min}$ of exposure we can already achieve approximately a fifth of the optimal yield.

In a second set of experiments, we focused on controlling the duration of translation. The experiments were performed as illustrated in Figure 3B. Translation was stopped by adding and retrieving bead-bound ssDNA with a sequence that is complementary to the produced mRNA (Figure 2, red circles and black squares). The blue triangles in Figure 2 show the kinetics after adding fresh, unbound DNA $A_{\text {deGFP }}$ to the sample immediately after mRNA removal.

Figure 2 shows that adding beads coated with ss-DNA complementary to the transcribed mRNA ( $3^{\prime}$ and poly-T) and their subsequent removal suppress further translation without affecting the ability of the cell-free system to perform further gene expressions.

We have shown that in our E. colicell-free expression system, gene expression occurs if linear, bead-bound DNA $A_{\text {deGFP }}$ is added. For other expression systems the usage of bead-bound DNA as the DNA source has already been reported [26]. The necessity to use a fivefold concentration of bead-bound DNA deGFP compared with unbound DNA ${ }_{\text {deGFP }}$ in bulk may be explained by lower accessibility of the bead-bound DNA $_{\text {deGFP. }}$. The biotin-streptavidin bond is known to be very strong $[27,28]$. We do not expect DNA $A_{\text {deGFP }}$ to leak from beads since during a few weeks at $4^{\circ} \mathrm{C}$ no decay with bead storage in stock solution could be detected. Moreover, reusing beads with different exposure times to cell-free reactions as the DNA deGFP $_{\text {source in new }}$ expression experiments produced the same deGFP expression level (Supplementary Figure S1). The fact that mRNA removal stops expression confirms that DNA $_{\text {deGFP }}$ leaking from beads into the cell-free reaction is negligible. Only the 
addition of fresh DNA again triggers protein expression (Figure 2).

We observed that the presence of DNA $_{\text {deGFP }}$ during $\mathrm{T}=30$ min leads to optimal protein yield (Figure 1). Shorter exposure times result in lower yields, explained by smaller amounts of transcribed mRNA. A small decrease in protein yield for longer exposure times may well be due to sharing effects of translation and transcription processes. DeGFP fluorescence quenching was never observed with our experiments at comparable concentrations (Supplementary Figure $\mathrm{S} 2$ ). The relatively high protein production observed for $\mathrm{T}=1 \mathrm{~min}$ and the fact that $\mathrm{T} \geq 20$ min yields a comparable level of deGFP with $\mathrm{T}=16 \mathrm{~h}$, suggest that mRNA is not a limiting factor for protein production as long as $\mathrm{T} \geq 20 \mathrm{~min}$.

The long lifetime of mRNA in the cell-free reaction is a likely cause for the minor increase of fluorescence intensity even after removal of DNA deGFP. $_{\text {. }}$ In principle, a delay in protein maturation could also cause an increase (Figure 2, black squares). However, maturation of deGFP requires 8 to $16.2 \mathrm{~min}[15,16]$, too short to explain the observed increase of fluorescence intensity over several hours. If mRNA lifetime was a limiting factor, the deGFP-mRNA mean lifetime could be calculated by fitting the timedependent production of matured deGFP from the moment where transcription is stopped (Figure 2, black squares) with a mathematical expression that describes mRNA inactivation as exponentially decaying $[15,16,29]$. Doing so results in a mean mRNA lifetime of about $124 \mathrm{~min}$.

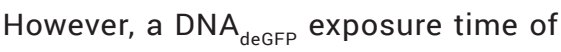
$30 \mathrm{~min}$ leads to a similar protein yield as exposure of over $16 \mathrm{~h}$ (Figure 1). We conclude that fatigue of our expression system, rather than mRNA degradation, is the main cause for saturation of deGFP production. Accordingly 124 min must be understood as a lower bound of the deGFP-mRNA lifetime. Previously the lifetime of mRNA was claimed to be short (E. coli: $6.8 \mathrm{~min}$; $E$. coli cell-free system: about 13 min $[3,16,29])$. However, mRNA stability depends on the particular cell-free system as well as the mRNA itself $[16,18,30]$. A possible reason for the difference could lie in the presence

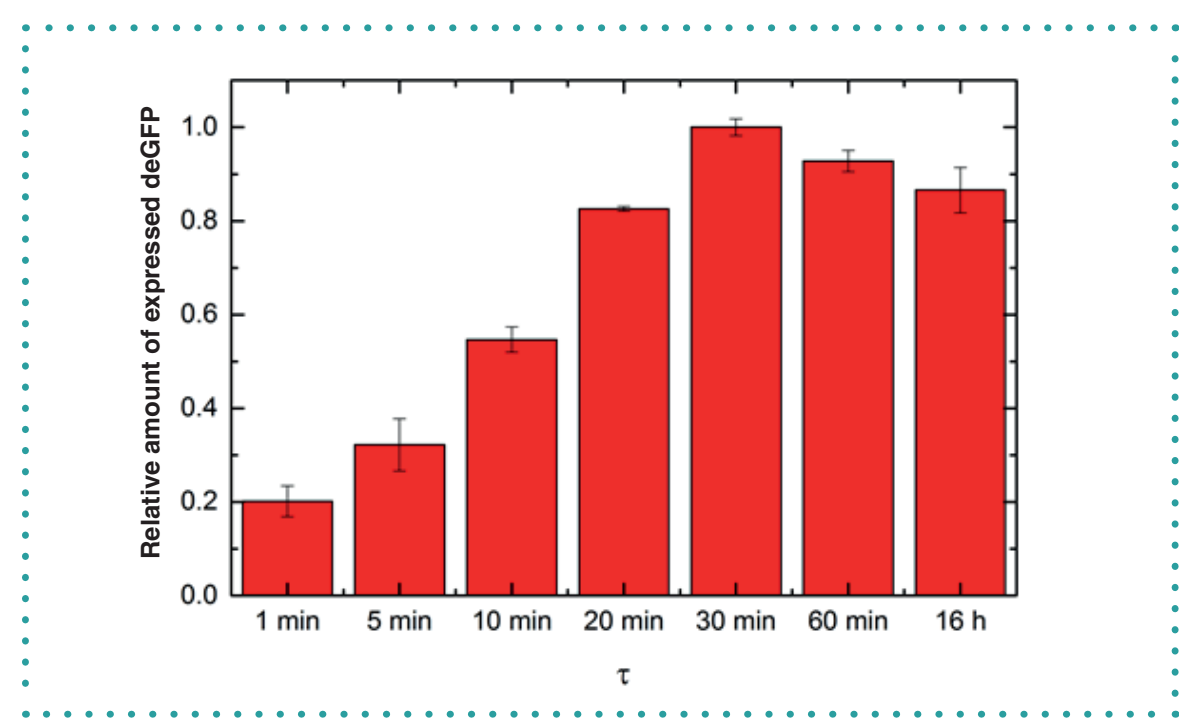

Figure 1. Relative amounts (normalized to the maximum) of expressed deGFP in a cell-free expression reaction after $16 \mathrm{~h}$ of incubation as a function of the time $\mathrm{T}$, the time interval that the cell-free system was in contact with bead-bound DNA deGFP. A DNA ${ }_{\text {deGFP }}$ exposure time of $30 \mathrm{~min}$ causes the highest level of deGFP production.

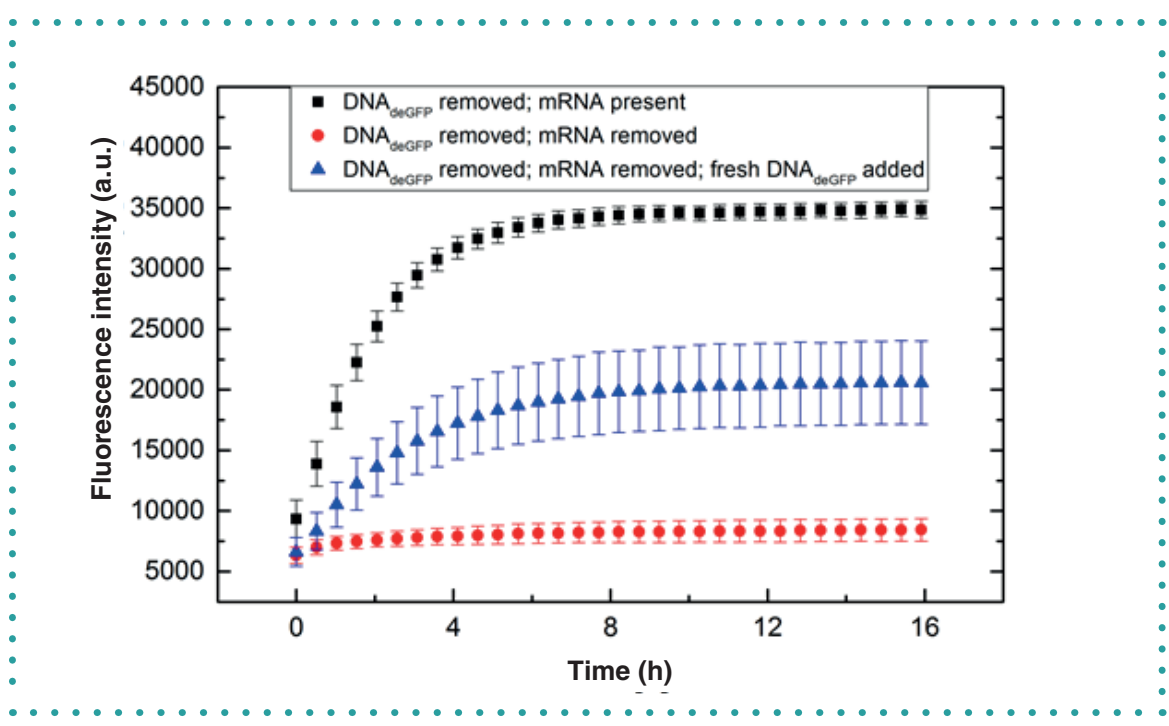

Figure 2. Time course of fluorescence intensity from deGFP as produced in a cell-free expression reaction. The samples were in contact with bead-bound DNA $A_{\text {deGFP }}$ (during $T=30$ min, not shown). After DNA deGFP removal the expression kinetics was monitored (i) without further modification of the expression system (black squares), (ii) after mRNA removal (red circles) and (iii) after mRNA removal and subsequent addition of fresh DNA (blue triangles). For mRNA removal ss-DNAcoated beads ( $3^{\prime}$ and poly-T, each $50 \mu \mathrm{l}$ ) were added and removed $15 \mathrm{~min}$ later (followed by the start of recording). We address the initial increase in (ii) to deGFP maturing and a small amount of residual mRNA. Adding fresh, unbound DNA ${ }_{\text {deGFP }}$ to the expression reaction restarted expression. To maintain overall concentration (iii) required pipetting of small volumes (about $0.1 \mu \mathrm{l}$ ) of highly concentrated DNA ${ }_{\text {deGFP' }}$ causing increased error.

of Gams in our case, which may affect mRNA degradation. Moreover, different methods to stop transcription will affect the expression system differently.

Figure 2 shows that treating mRNA containing cell-free systems ( no DNA $_{\text {deGFP }}$ ) for 15 min with bead-bound ss-DNA complementary to the mRNA sequence stops protein production and, by extension, translation. We suggest that the formation of a DNA-mRNA hybrid [31] removes free mRNA almost completely. The small increase in fluorescence intensity during the first minutes (Figure 2) can be explained by expressed deGFP that matured within this time frame 


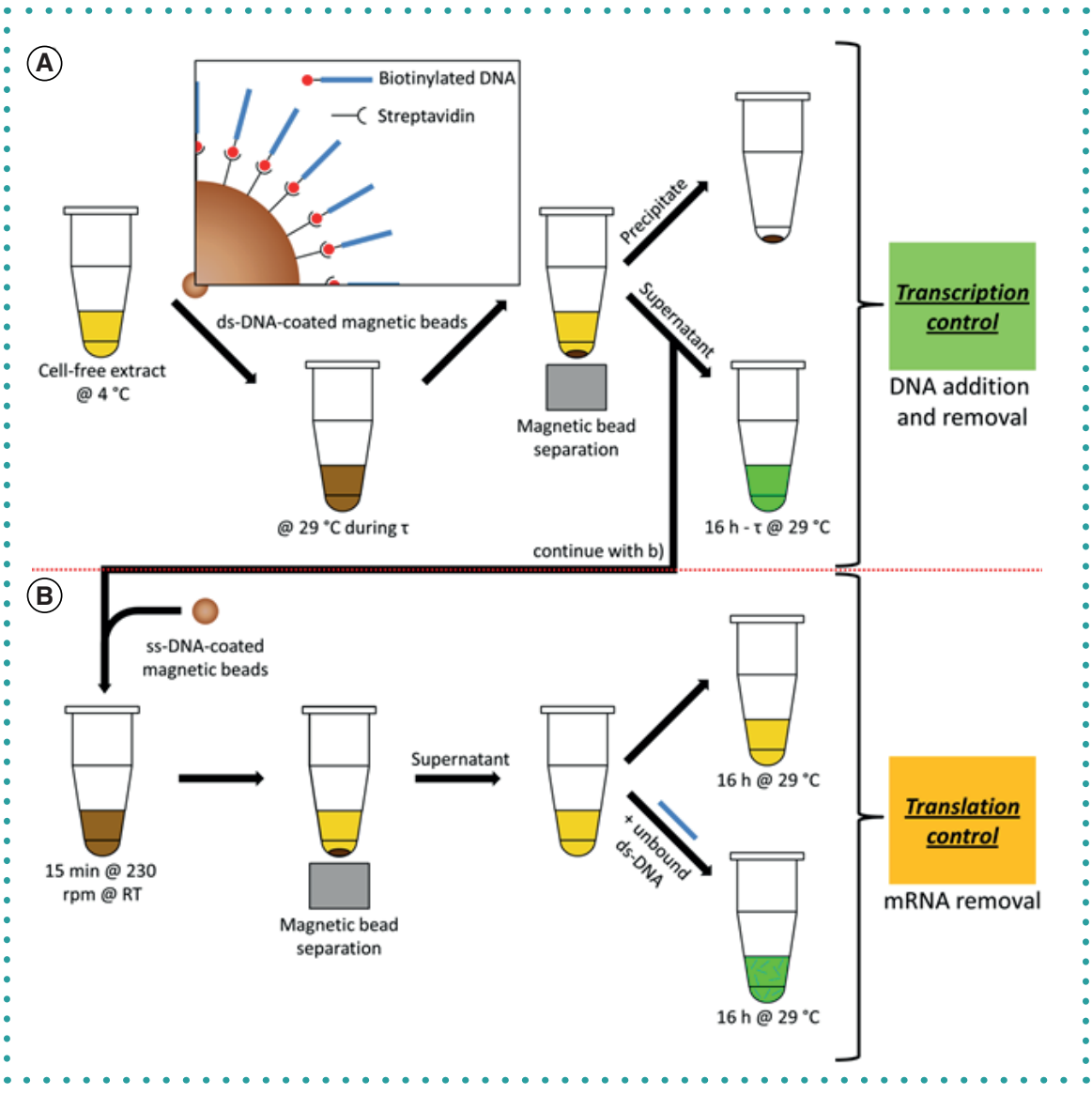

Figure 3. Scheme of experiments addressing control of transcription as well as translation. (A) For transcription control, $\mathrm{DNA}_{\text {deGFP }}$-coated magnetic beads are added to a cell-free reaction followed by incubation at $29^{\circ} \mathrm{C}$ during the time interval T. Bead-bound DNA $A_{\text {deGFP }}$ is then removed by magnetic separation. The supernatant is incubated for $16 \mathrm{~h}-\mathrm{T}$ at $29^{\circ} \mathrm{C}$. During this time interval the amount of expressed protein is monitored (Figure 2 black squares, end points Figure 1). (B) To stop translation, magnetic beads coated with ss-DNA complementary to the transcribed mRNA are added immediately after DNA removal. Then the sample is mixed for $15 \mathrm{~min}$ on a shaker $(230 \mathrm{rpm}$, room temperature) followed by magnetic separation of the beads. Expression is suppressed (Figure 2, red circles). Further expression reactions can be performed again by addition of fresh DNA (Figure 2, blue triangles).

D in conjunction with a small amount of remaining mRNA. The fact that gene expression restarts upon adding fresh DNA $_{\text {deGFP }}$ shows that the expression system is not affected by bead treatment.

A possible application of the latter is the removal of residual canonical amino acids within the cell-free system for the incorporation of noncanonical amino acids. If the canonical amino acid is still present within the system, it will be preferably incorporated instead of the noncanonical one [32]. Using the method proposed here, a first expression can be performed to incorporate the residual canonical amino acid into a dummy protein, followed by addition of the corre- sponding noncanonical amino acid in a second expression reaction.

The method enables spatially and temporally separated expression of several, different genes: beads coated with different DNA can be successively added and removed from the expression reaction. Simultaneous co-expression of several genes in cell-free systems results in competition for the expression machinery, making the control of individual expression rates difficult; a situation that our method can help to avoid. In principle, any cell-free system should remain unaltered following the protocol presented here. Our method can be used for any linear, biotinylated DNA-construct.
In this paper, we demonstrated a new and simple method for controlling the expression duration within a cell-free expression system. The method acts on two different levels, transcription and translation, without biochemically altering the expression system. DNA-coated beads are used to provide and remove the DNA of the gene of interest, or to remove the corresponding mRNA. We achieve good temporal control. Spatial control of gene expression through the arrangement of magnetic beads can also be useful, for example, in microfluidic experiments.

\section{FUTURE PERSPECTIVE}

The proposed method regulates gene expression by nothing but spatiotemporal separation of the nucleic acids without usage of any other biochemical substances. This way, the gene expression system remains chemically unaltered while controlling gene expression very accurately. Gene expression can be triggered in a defined location by applying magnetic fields on paramagnetic DNA-coated beads. This can be of use in microfluidics. Another field of application of the method proposed here is the incorporation of noncanonical amino acids into proteins by including them into the expression system. Proteins with noncanonical analogs may develop new functions in the organism. In cell-free extracts, however, there are residual amino acids that suppress the simple incorporation of their noncanonical analogs. With our technique we are able, in a first expression reaction, to incorporate the canonical amino acids into a dummy protein followed by a second expression reaction using noncanonical analogs. Furthermore, our method may be an interesting tool in the field of nanomaterials. Bead-bound DNA caged within a material that can release the DNA in response to an outer stimulus may be a way to enable protein synthesis as response to a stimulus.

\section{AUTHOR CONTRIBUTIONS}

$\mathrm{AO}$ and MF designed the research, MF performed the research and analyzed data with the help of $\mathrm{AO}$. MF and $\mathrm{AO}$ wrote the paper. 


\section{FINANCIAL DISCLOSURE}

This work was supported by the Collaborative Research Center SFB 1027 funded by Deutsche Forschungsgemeinschaft (DFG) and by the Human Frontier Science Program (HFSP, RGP0037/2015). The authors have no other relevant affiliations or financial involvement with any organization or entity with a financial interest in or financial conflict with the subject matter or materials discussed in the manuscript apart from those disclosed.

No writing assistance was utilized in the production of this manuscript.

\section{ACKNOWLEDGMENTS}

We thank Emanuel Worst and Vincent Noireaux for help and fruitful discussions. We thank Mina Mohammadi-Kambs for fitting our data to estimate the deGFPmRNA mean lifetime.

\section{OPEN ACCESS}

This work is licensed under the AttributionNonCommercial-NoDerivatives 4.0 Unported License. To view a copy of this license, visit http://creativecommons.org/ licenses/by-nc-nd/4.0/

\section{SUPPLEMENTARY DATA}

To view the supplementary data that accompany this article please visit the journal website at www.future-science. com/doi/suppl/10.2144/btn-2018-0097

\section{REFERENCES}

1. Schachtele CF, Rogers P. Canavanine death in Escherichia coli. J. Mol. Biol. 14, 474-489 (1965).

2. Worst EG, Exner MP, DeSimone A et al. Cell-free expression with the toxic amino acid canavanine. Bioorg. Med. Chem. Lett. 25, 3658-3660 (2015).

3. Shin J, Noireaux V. An E. coli cell-free expression toolbox: application to synthetic gene circuits and artificial cells. ACS Synth. Biol. 1, 29-41 (2012)

4. Weber W, Fussenegger M. Emerging biomedical applications of synthetic biology. Nat. Rev. Genet. 13, 21-35 (2012).

5. Michalodimitrakis $\mathrm{K}$, Isalan $\mathrm{M}$. Engineering prokaryotic gene circuits. FEMS Microbiol. Rev. 33, 27-37 (2009).

6. Endy D. Foundations for engineering biology. Nature 438, 449-453 (2005).

7. Polstein LR, Gersbach CA. Light-inducible spatiotemporal control of gene activation by customizable zinc finger transcription factors. J. Am. Chem. Soc. 134 16480-16483 (2012).

8. Bikard D, Jiang W, Samai P et al. Programmable repression and activation of bacterial gene expression using an engineered CRISPR-Cas system. Nucleic Acids Res. 41, 7429-7437 (2013).

9. Schenkelberger M, Shanak S, Finkler $M$ et al. Expression regulation by a methyl-CpG binding domain in an E. coli based, cell-free TX-TL system. Phys. Biol. 14(2), 026002 (2017).

10. Kaludov NK, Wolffe AP. MeCP2 driven transcriptional repression in vitro: selectivity for methylated DNA, action at a distance and contacts with the basal transcription machinery. Nucleic Acids Res. 28, 1921-1928 (2000).
11. Pinheiro A, Baptista $P$, Lima JC. Light activation of transcription: photocaging of nucleotides for control over RNA polymerization. Nucleic Acids Res. 36, 1-7 (2008).

12. Shimizu-Sato S, Huq E, Tepperman JM, Quail PH. A light-switchable gene promoter system. Nat. Biotechnol. 20, 1041-1044 (2002).

13. Polstein LR, Gersbach CA. A light-inducible CRISPR/ Cas 9 system for control of endogenous gene activation. Nat. Chem. Biol. 11, 198-200 (2015).

14. Sander JD, Joung JK. CRISPR-Cas systems for editing regulating and targeting genomes. Nat. Biotechnol. 32, 347-355 (2014)

15. Garamella J, Marshall R, Rustad M, Noireaux V. The all E. coli TX-TL toolbox 2.0: a platform for cell-free synthetic biology. ACS Synth. Biol. 5, 344-355 (2016)

16. Shin J, Noireaux V. Study of messenger RNA inactivation and protein degradation in an Escherichia coli cell-free expression system. J. Biol. Eng. 4, 1-9 (2010).

17. Sarkar N. Polyadenylation of mRNA in prokaryotes. Annu. Rev. Biochem. 66, 173-197 (1997).

18. Bernstein JA, Khodursky AB, Lin PH, Lin-Chao $S$ Cohen SN. Global analysis of mRNA decay and abundance in Escherichia coli at single-gene resolution using two-color fluorescent DNA microarrays. Proc. Natl Acad. Sci. USA 99, 9697-9702 (2002)

19. Sun ZZ, Hayes CA, Shin J et al. Protocols for implementing an Escherichia coli based TX-TL cell-free expression system for synthetic biology. J. Vis. Exp. 79, 2013).

20. Shin J, Noireaux V. Efficient cell-free expression with the endogenous $E$. Coli RNA polymerase and sigma factor 70. J. Biol. Eng. 4, 8 (2010).

21. Invitrogen. Manual for Dynabeads" MyOne ${ }^{\mathrm{N}}$ Streptavidin T1. (2017).

22. Takahashi MK, Hayes CA, Chapell J et al. Characterizing and prototyping genetic networks with cell-free transcription-translation reactions. Methods 86 60-72 (2015)
23. Sitaraman K, Esposito D, Klarmann G et al. A nove cell-free protein synthesis system. J. Biotechnol. 110, 257-263 (2004).

24. Sun ZZ, Yeung E, Hayes CA, Noireaux V, Murray RM. Linear DNA for rapid prototyping of synthetic biological circuits in an Escherichia coli based TX-TL cell-fre system. ACS Synth. Biol. 3, 387-397 (2014).

25. Ambion. Manual for Dynabeads ${ }^{\circledR}$ Oligo (dT)25. (2012).

26. Nord O, Uhlén M, Nygren PÅ. Microbead display of proteins by cell-free expression of anchored DNA. $J$. Biotechnol. 106, 1-13 (2003).

27. Weber $P$, Ohlendorf $D$, Wendoloski J, Salemme $F$. Structural origins of high-affinity biotin binding to streptavidin. Science 243, 85-88 (1989).

28. Chivers CE, Koner AL, Lowe ED, Howarth M. How the biotin-streptavidin interaction was made even strong er investigation via crystallography and a chimaeric tetramer. Biochem. J. 435, 55-63 (2011).

29. Selinger DW, Saxena RM, Cheung KJ, Church GM, Rosenow C. Global RNA half-life analysis in Escherichia coli reveals positional patterns of transcript degradation. Genome Res. 13, 216-223 (2003).

30. Belasco JG, Higgins CF. Mechanisms of mRNA decay in bacteria: a perspective. Gene 72, 15-23 (1988).

31. Naiser T, Ehler O, Kaiser J, Mai T, Michel W, Ott A. Impact of point-mutations on the hybridization affinity of surface-bound DNA/DNA and RNA/DNA oligonucleotide-duplex: and base bulges. BMC Biotechnol. 8, 1-23 (2008).

32. Worst EG, Exner MP, DeSimone A, Schenkelberger M et al. Residue-specific incorporation of noncanonical amino acids into model proteins using an Escherichia coli cell-free transcription-translation system. J. Vis. Exp. 114, 1-14 (2016).

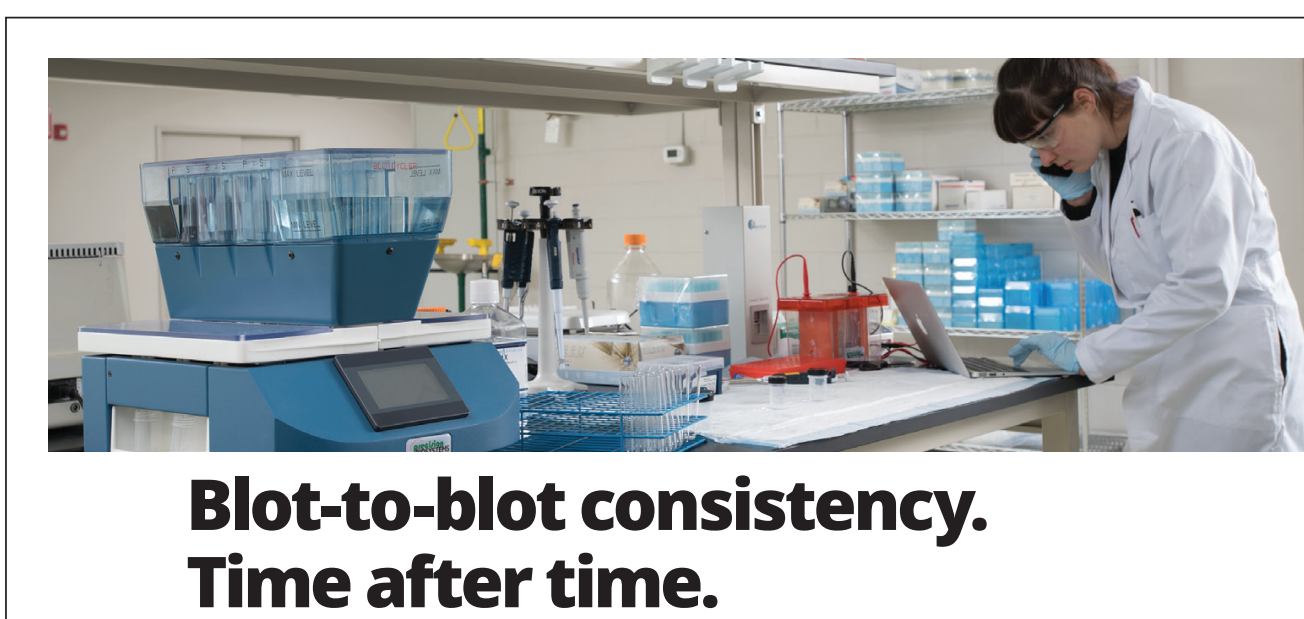

To achieve meaningful comparison of expressed proteins

from blot-to-blot, trustworthy data is essential. BlotCycler ${ }^{\mathrm{TM}}$ is designed to eliminate slight variations in fluid delivery, timing and washing that may occur when protocols are performed

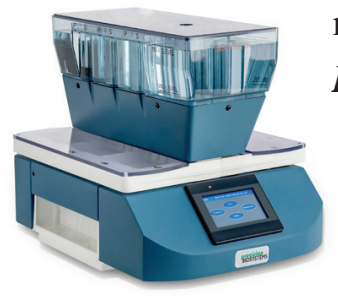
manually. With rigorous precision, BlotCycler delivers an affordable solution to busy labs demanding reproducible results.

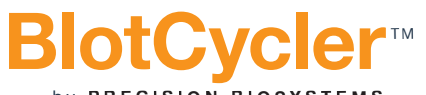

www.blotcycler.com 